\section{Increased mast cell numbers in the conjunctiva of glaucoma patients: a possible indicator of preoperative glaucoma surgery inflammation}

L Chang 1,2, T Wong1', M Ohbayashi ${ }^{3}$, C Bunce ${ }^{4}$,

K Barton' ${ }^{1}$, S Ono ${ }^{3}$ and PT Khaw ${ }^{5,6}$

\begin{abstract}
Purpose Inflammation is a risk factor for scarring after trabeculectomy surgery. Mast cells are important mediators of inflammation and scarring in allergic eye disease. This exploratory project investigated the presence of mast cells in the conjunctiva of glaucoma patients having trabeculectomy surgery. Methods Conjunctival biopsies from glaucoma patients belonging to specific groups: medically treated glaucoma $(M, n=6)$, repeat glaucoma surgery $(S, n=8)$, and uveitic glaucoma $(U, n=7)$. The control group $(C$, $n=8$ ) was retinal detachment patients undergoing repair surgery for the first time. Immunohistochemistry techniques stained for the presence of the intracellular mast cell enzyme tryptase.

Results The median mast cell tryptasepositive counts for all glaucoma groups $(M, S$, and $U$ ) ranged from $0.102-0.113$ cells $/ \mathrm{mm}^{2}$ compared to 0.064 cells $/ \mathrm{mm}^{2}$ for group C. This was statistically significant comparing group $S$ to group $C(P=0.0063)$, but not when comparing groups $U$ or $M$ to group $C$. The mast cell tryptase-positive counts did not significantly differ among the groups. Conclusions Mast cell numbers were significantly increased in glaucoma patients who have previously undergone surgery (group S). Mast cell activity may contribute to the scarring process and the increased risk of excessive conjunctival scarring after trabeculectomy surgery. Further investigation needs to be performed to evaluate this potential role.
\end{abstract}

Eye (2009) 23, 1859-1865; doi:10.1038/eye.2008.330; published online 24 October 2008

Keywords: mast cell; inflammation; wound healing; glaucoma

\section{Introduction}

Inflammation is an important clinical risk factor for excessive scarring after glaucoma filtration surgery. Early onset postoperative failures (less than 6 months) have been reported to show a marked inflammatory response and excessive conjunctival scarring. ${ }^{1}$ Glaucoma filtration surgery is not usually recommended until maximal medical treatment has been tried. However, it has been suggested that the prolonged topical treatment may have a prejudicial effect on the conjunctival cellular profile of some glaucoma patients, leading to an increased risk of excessive conjunctival scarring following glaucoma filtration surgery. ${ }^{2}$

Mast cells have been implicated as the key effector cells in allergic inflammation and the development of abnormal conjunctival scarring in the allergic eye disease, vernal keratoconjunctivitis (VKC). ${ }^{3}$ Mast cells have been studied in dermal wound healing; however, their role in conjunctival wound healing after trabeculectomy surgery has not been established.

The aim of this study was to investigate the potential role of mast cells in conjunctival wound healing in glaucoma patients. This was an exploratory study to establish whether there was a difference in the mast cell profile in
'Department of Glaucoma, Moorfields Eye Hospital NHS Foundation Trust, London, UK

${ }^{2}$ Ocular Repair and Regeneration Biology Unit, UCL Institute of Ophthalmology, London, UK

${ }^{3}$ Department of Ocular Immunology, UCL Institute of Ophthalmology, London, UK

${ }^{4}$ Research \& Development Department, Moorfields Eye Hospital NHS Foundation Trust, London, UK

${ }^{5}$ Paediatric Glaucoma Service, Moorfields Eye Hospital, London, UK

${ }^{6}$ Ocular Repair and Regeneration Biology Unit, UCL Institute of Ophthalmology and National Institute for Health Research, Biomedical Research Centre, London, UK

Correspondence: L Chang, C/O Debbie Bryant, Paediatric Glaucoma Service,

Department of Glaucoma, Moorfields Eye Hospital NHS Foundation Trust, 11-43 Bath Street, London EC1V 9EL, UK. Tel: + 44207566 2334; Fax: + 442075662334 . E-mail: lydia742@ btinternet.com

Received: 20 August 2008 Accepted in revised form: 28 September 2008 Published online: 24 October 2008 
glaucoma patients compared with a control group of patients who had never been medicated and with no history of allergic eye disease.

\section{Materials and methods}

This study was approved by the ethics committee of Moorfields Eye Hospital NHS Foundation Trust. Glaucoma and vitreoretinal patients about to undergo surgery were consented for a peroperative conjunctival biopsy. Glaucoma patients belonged to three groups: patients on glaucoma medical treatment about to undergo primary filtration surgery $(\mathrm{M})$, uveitic glaucoma patients about to undergo primary filtration surgery (U), and glaucoma patients who had failed previous filtration surgery, that is, scarrers about to undergo repeat filtration surgery (S). The control group (C) was represented by vitreoretinal patients, who had never been medicated and were about to undergo retinal detachment surgery for the first time. Patients with a previous history of allergic eye disease were excluded.

Biopsy specimens were obtained from the superior bulbar conjunctiva at the conjunctival edge where the filtration surgery was being performed. A biopsy approximately $2-3 \mathrm{~mm}^{2}$ was obtained, fixed in formaldehyde, and embedded in paraffin wax. Four micron thick sections were deparaffinised using xylene and then rehydrated using industrial methylated spirit. Antigen retrieval was performed by microwave, heating the sections in tris urea (pH9.5) at full power for $2.5 \mathrm{~min}$, four times.

The Dako REAL ${ }^{\mathrm{TM}}$ Detection System (K5001 Dako) was used with a Dako automated immunostaining machine to stain the sections. This system is based on the labelled streptavidin-biotin method in a three-step procedure. The first step was incubation for $1 \mathrm{~h}$ with the primary antibody for mast cells (1:600 M7052 Dako) or for alpha smooth muscle actin (1 : 100 M0851 Dako). The second step was incubation for 35 min with Dako REAL $^{\mathrm{TM}}$ Link, Biotinylated Secondary Antibodies (AB2 Dako), and the third step was incubation for $35 \mathrm{~min}$ with Dako REAL ${ }^{\text {TM }}$ Streptavidin Peroxidase (HRP Dako). The reaction was visualised using the Dako REAL ${ }^{\mathrm{TM}}$ diaminobenzidine (DAB Dako) chromogen. Endogenous peroxidase was blocked with Dako REAL ${ }^{\mathrm{TM}}$ peroxidase blocking solution (S2023 Dako). The sections were counterstained with Mayer's haemalum (350604T BDH), and then mounted with DePeX (361254D BDH). The positive control tissue for the mast cell staining was tonsil and for alpha smooth-muscle actin staining was rhabdomyosarcoma. The first layer was omitted for the negative control.

The stained sections were photographed using a software programme, Analysis ${ }^{\Lambda} \mathrm{D}$ (Olympus Soft Imaging Solutions $\mathrm{GmbH}$, Germany). Cell counts from two or three representative fields (depending on the size of the section) were chosen under $\times 20$ magnification, and the software enabled the surface area to be calculated. Statistical analysis was conducted to look for differences in the median cell count per unit surface area $\left(\mathrm{mm}^{2}\right)$ between the groups.

\section{Results}

The demographic details of the patients biopsied are summarised in Table 1. The glaucoma patients were divided into three groups: medicated (M), uveitic (U), and scarred (S). The glaucoma patients were nearly all taking glaucoma medications. The control patients (group C) consisted of vitreoretinal patients undergoing retinal detachment surgery for the first time having never taken any eye drops. Patients belonging to different ethnic groups were in all groups except for the control group, which consisted of Caucasians only.

Mast cells were located in the conjunctival substantia propria and were not observed in the conjunctival epithelium. Tryptase staining was observed in two ways: intracellular staining before mast cell degranulation and granular and diffusely spread staining after mast cell degranulation (Figure 1). The median total cell counts for the medicated (M), uveitic (U), scarred (S) glaucomas, and control (C) groups are shown in Table 2 (represented in Figure 2). The data were not normally distributed so the non-parametric Wilcoxon rank-sum test was used to evaluate for statistical differences. There was strong evidence that the total cell counts were significantly higher in all glaucoma groups compared with group $\mathrm{C}$. There was no statistically significant difference in total cell number when comparing the glaucoma groups to each other.

The median mast cell counts for groups M, U, S, and C are shown in Table 2 and Figure 3. The median mast cell count for group $\mathrm{S}$ compared with group $\mathrm{C}$ was significantly higher $(P=0.0063)$. The median mast cell count was higher for groups $M$ compared with group $C$; however, this was not statistically significant at the 0.05 level $(P=0.07)$. The median mast cell count was higher for group $U$ compared with group $C$, and again this difference was not statistically significant $(P=0.165)$. In all the glaucoma groups, about half of the patients had a median mast cell tryptase (MCT) count more than 10 times greater than the control group median MCT count. There was no statistically significant difference in mast cell number when comparing the glaucoma groups to each other. Alpha smooth-muscle actin staining was only weakly positive in a few patients and was similar throughout all the groups (staining not shown).

We investigated any differences in the conjunctival cellular profile depending on ethnic grouping (Table 2). If Caucasians from all groups $(n=22$, including the control 
Table 1 Demographic details of the patients studied including their glaucoma medical eye-drop history at the time of conjunctival biopsy

\begin{tabular}{|c|c|c|c|c|c|c|c|c|c|c|c|c|}
\hline \multirow[t]{2}{*}{ Patient ID } & \multirow[t]{2}{*}{ Group } & \multirow[t]{2}{*}{ Ethnicity } & \multirow{2}{*}{$\begin{array}{l}\text { Age } \\
\text { (years) }\end{array}$} & \multicolumn{6}{|c|}{ Drops at biopsy } & \multirow{2}{*}{$\begin{array}{l}\text { Mast cell } \\
\text { Count } / \mathrm{mm}^{2}\end{array}$} & \multirow{2}{*}{$\begin{array}{l}\text { Total cell } \\
\text { count } / \mathrm{mm}^{2}\end{array}$} & \multirow{2}{*}{$\begin{array}{l}\text { Percentage of total } \\
\text { cell population }\end{array}$} \\
\hline & & & & $B B$ & $P g$ & $C A I$ & $A / B$ & Pilo & Others & & & \\
\hline 1 & M & $\mathrm{A}$ & 79 & + & + & & + & & Vexol & 0.135 & 1.46 & 9.23 \\
\hline 2 & M & A & 55 & + & + & & + & + & & 0.194 & 4.38 & 4.42 \\
\hline 3 & M & $A-C$ & 66 & + & + & & + & & & 0.271 & 2.90 & 9.35 \\
\hline 4 & M & $\mathrm{C}$ & 46 & + & & + & + & & & 0.092 & 1.84 & 5.03 \\
\hline 5 & M & $\mathrm{C}$ & 74 & + & + & + & & & & 0.049 & 0.69 & 7.09 \\
\hline 6 & M & $\mathrm{C}$ & 20 & + & + & + & & & & 0.091 & 1.43 & 6.37 \\
\hline 7 & $\mathrm{U}$ & $\mathrm{C}$ & 25 & + & + & + & & & Dex & 0.304 & 2.39 & 12.72 \\
\hline 8 & $\mathrm{U}$ & $\mathrm{C}$ & 25 & + & + & + & + & & Dex & 0.014 & 1.05 & 1.36 \\
\hline 9 & $\mathrm{U}$ & $\mathrm{C}$ & 33 & + & + & & + & & & 0.039 & 0.77 & 5.03 \\
\hline 10 & $\mathrm{U}$ & $\mathrm{A}$ & 47 & & & & & & Dex & 0.097 & 1.08 & 8.97 \\
\hline 11 & $\mathrm{U}$ & $\mathrm{C}$ & 59 & & + & & + & & & 0.102 & 2.49 & 4.08 \\
\hline 12 & $\mathrm{U}$ & A & 38 & + & + & + & & & & 0.203 & 2.76 & 7.35 \\
\hline 13 & $\mathrm{U}$ & Turkish & 44 & + & + & + & & & & 0.128 & 0.89 & 14.44 \\
\hline 14 & $S$ & C & 39 & & & & & & & 0.145 & 2.07 & 7.03 \\
\hline 15 & $S$ & $A-C$ & 39 & + & + & + & + & & & 0.093 & 0.86 & 10.84 \\
\hline 16 & $S$ & C & 37 & + & + & + & & & & 0.093 & 0.41 & 22.50 \\
\hline 17 & $S$ & $\mathrm{~A}-\mathrm{C}$ & 46 & + & + & & & & Exocin & 0.111 & 1.43 & 7.71 \\
\hline 18 & $S$ & C & 74 & & + & & & & Dex & 0.500 & 1.50 & 33.43 \\
\hline 19 & $S$ & $A-C$ & 44 & + & + & + & + & + & & 0.120 & 2.13 & 5.64 \\
\hline 20 & $S$ & $\mathrm{C}$ & 39 & + & + & + & & & & 0.082 & 0.66 & 12.38 \\
\hline 12 & $S$ & $\mathrm{C}$ & 64 & & + & + & & + & & 0.094 & 1.68 & 5.58 \\
\hline 22 & $\mathrm{C}$ & $\mathrm{C}$ & 52 & & & & & & & 0.058 & 0.54 & 10.73 \\
\hline 23 & $\mathrm{C}$ & $\mathrm{C}$ & 57 & & & & & & & 0.091 & 0.74 & 12.23 \\
\hline 24 & $\mathrm{C}$ & $\mathrm{C}$ & 71 & & & & & & & 0.045 & 0.50 & 9.02 \\
\hline 25 & $\mathrm{C}$ & $\mathrm{C}$ & 56 & & & & & & & 0.064 & 0.97 & 6.59 \\
\hline 26 & $\mathrm{C}$ & $\mathrm{C}$ & 38 & & & & & & & 0.064 & 0.75 & 8.52 \\
\hline 27 & $\mathrm{C}$ & $\mathrm{C}$ & 46 & & & & & & & Staining to & granular & \\
\hline 28 & $\mathrm{C}$ & $\mathrm{C}$ & 49 & & & & & & & 0.087 & 0.64 & 13.71 \\
\hline 29 & $\mathrm{C}$ & $\mathrm{C}$ & 61 & & & & & & & 0.059 & 0.43 & 13.63 \\
\hline 30 & $\mathrm{C}$ & $\mathrm{C}$ & 61 & & & & & & & 0.096 & 0.43 & 22.40 \\
\hline
\end{tabular}

$\mathrm{A} / \mathrm{B}=$ apraclonidine/brimonidine, $\mathrm{BB}=\beta$-blocker, $\mathrm{CAI}=$ carbonic anhydrase inhibitor, $\mathrm{Dex}=$ dexamethasone; $\mathrm{Pg}=$ prostaglandin analogue, Pilo $=$ pilocarpine.

The patient groups were $\mathrm{M}, \mathrm{U}, \mathrm{S}$, and $\mathrm{C}$. $\mathrm{M}=$ medicated; $\mathrm{U}=$ uveitic; $\mathrm{S}=$ scarred; $\mathrm{C}=$ control. Patients' ethnicity was documented as $\mathrm{A}=\mathrm{Asians}$, $\mathrm{C}=$ Caucasian, and $\mathrm{A}-\mathrm{C}=$ Afro-Caribbean. The topical drug history was taken at the time of biopsy and is marked + , if the patient was taking a particular type of topical drug.

group) were compared with Afro-Caribbean patients $(n=8)$, the median total cell count was $1.00 / \mathrm{mm}^{2}$ for the Caucasian population compared to $1.79 / \mathrm{mm}^{2}$ for the Afro-Caribbean population. The median mast cell count was $0.089 / \mathrm{mm}^{2}$ for the Caucasian population compared to $0.13 / \mathrm{mm}^{2}$ for the Afro-Caribbean population. A two sample Wilcoxon rank-sum (Mann-Whitney) test indicated that there appeared to be significantly lower total cell and mast cell counts $(P=0.01$ and $P=0.006$, respectively).

However, if the Caucasian control patients were not included in the analysis, the median total cell count was $1.43 / \mathrm{mm}^{2}$ for the Caucasian population $(n=11)$ and $1.79 / \mathrm{mm}^{2}$ for the Afro-Caribbean population $(n=8)$. The median mast cell count was $0.092 / \mathrm{mm}^{2}$ for the Caucasian population and $0.13 / \mathrm{mm}^{2}$ for the Afro-Caribbean population. There was no significant difference in total cell counts $(P=0.16)$ and mast cell counts $(P=0.070)$ when comparing these ethnic groups.

\section{Discussion}

This study has shown that the cellularity of conjunctival tissue is increased in all glaucoma patients compared with control patients. It has also shown that MCT staining was significantly increased in glaucoma patients who have undergone previous filtration surgery. Although the median tryptase-positive mast cell counts 

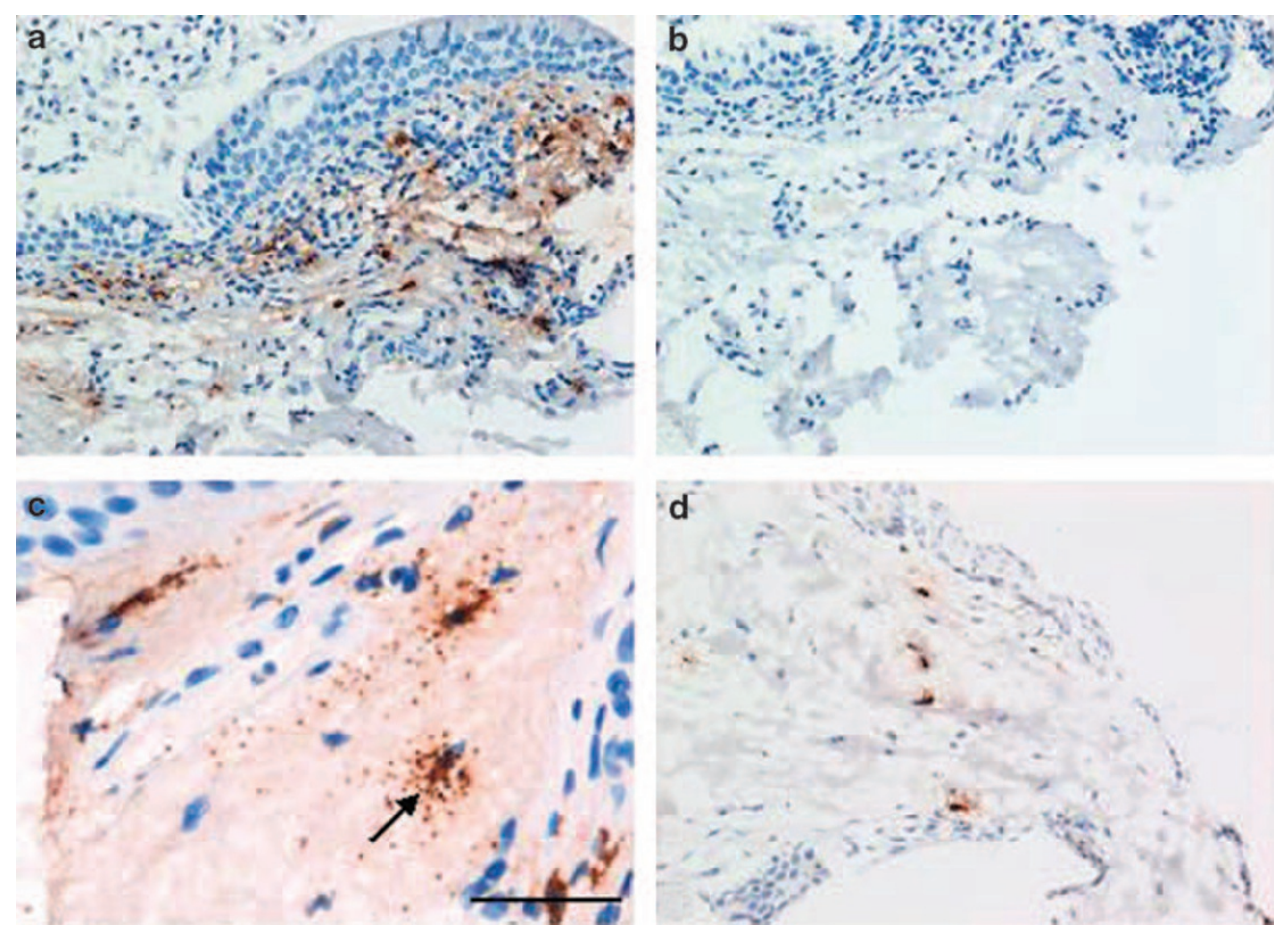

Figure 1 Mast cell tryptase staining in human conjunctiva (a and c) with the negative control showing no staining (b). Mast cell degranulation showing discharged cell contents diffusely spread around cells (c, arrow). Scale bar $=100 \mu \mathrm{m}$.

were higher in the uveitic glaucoma and medicated glaucoma patients, the difference was not statistically significant.

Mast cells can be differentiated into MCT-only-positive cells and MCT and chymase (MCTC)-positive cells. ${ }^{4}$ In the skin, the mast cell population has been reported to consist almost exclusively of MCT cells. Other investigators have previously reported the existence of mast cells in human conjunctiva-McMillan $e t a l^{5}$ and Broadway et $a l^{6}$ reported a higher mast cell count in Caucasians compared with Afro-Caribbean patients. Our study did not find any significant differences in total and mast cell counts between these ethnic groups when only glaucoma patients were analysed. However, when the control group (of Caucasians only) was included in the analysis, there were significantly greater total and mast cell counts in the Afro-Caribbean compared with the Caucasian population. The explanation for these findings could be that the taking of glaucoma eye drops (irrespective of ethnicity) increased the conjunctival cellular profile. We did not have a control group of AfroCaribbean patients, so we were unable to compare cell counts in unmedicated patients.

Mast cells may play an important role in wound healing as shown by Trautmann $e t a l^{7}$ who identified tryptase-positive mast cells in foci of lymphocytes and macrophages in serial biopsies taken from incisional wounds made in the skin of human volunteers. Cell numbers increased between days 4 and 10 reaching a maximum (five times the baseline) on day 10. Numbers were increased through recruitment and retention rather than proliferation.

The exact role of mast cells in wound healing is not yet clearly defined. In one study, almost $70 \%$ of tryptasepositive mast cells stained strongly for the interleukin-4, a cytokine that stimulated fibroblast proilferation. ${ }^{8}$

However, another study suggested that mast cells might influence the inflammatory rather than the proliferative phase in skin wound healing by reporting that the wounded mast cell-deficient mice only showed a reduction in neutrophil recruitment. ${ }^{9}$ Mast cells could have varying levels of importance in wound healing at different body sites. Beer et al ${ }^{10}$ reported significantly more mast cells in periocular scars, although there was no difference in the number of tryptase-positive mast cells in surgical compared with hypertrophic and keloid scars.

Mast cells may play an important role in the fibrotic process of chronic allergic eye diseases such as VKC. ${ }^{11}$ Expression of basic fibroblast growth factor (bFGF) was reported in $46 \%$ of mast cells in VKC patients, and an in vitro study showed histamine increased conjunctival proliferation, migration and procollagen production. ${ }^{12}$ Also, mast cells may play a role in the fibrogenic processes of pterygia, as mast cell numbers and expression of the bFGF were increased. ${ }^{13}$ 
Table 2 Median total and mast cell counts for the different categories of patients and for different ethnic groups

\begin{tabular}{|c|c|c|}
\hline Group & $\begin{array}{l}\text { Median total cell } \\
\text { count (number of } \\
\left.\text { cells } / \mathrm{mm}^{2}\right)\end{array}$ & $\begin{array}{c}P \text { (comparing } \\
\text { glaucoma groups to } \\
\text { group } \mathrm{C})\end{array}$ \\
\hline $\mathrm{M}(n=6)$ & 1.647 & 0.007 \\
\hline $\mathrm{U}(n=7)$ & 1.083 & 0.003 \\
\hline $\mathrm{S}(n=8)$ & 1.465 & 0.036 \\
\hline$C(n=8)$ & 0.590 & \\
\hline Group & $\begin{array}{l}\text { Median mast cell } \\
\text { count (number of } \\
\text { cells } / \mathrm{mm}^{2} \text { ) }\end{array}$ & $\begin{array}{c}P \text { (comparing } \\
\text { glaucoma groups to } \\
\text { group } \mathrm{C})\end{array}$ \\
\hline \multirow{5}{*}{$\begin{array}{l}\mathrm{M}(n=6) \\
\mathrm{U}(n=7) \\
\mathrm{S}(n=8) \\
\mathrm{C}(n=8)\end{array}$} & 0.113 & 0.07 \\
\hline & 0.102 & 0.165 \\
\hline & 0.102 & 0.0063 \\
\hline & 0.064 & \\
\hline & $\begin{array}{c}\text { Caucasian (including } \\
\text { controls) }\end{array}$ & Afro-Caribbeans \\
\hline \multirow{3}{*}{$\begin{array}{l}\text { Median total cell count } \\
\text { (number of cells } / \mathrm{mm}^{2} \text { ) } \\
n=22 \\
\text { Median mast cell count } \\
\text { (number of cells } / \mathrm{mm}^{2} \text { ) } \\
n=8\end{array}$} & 1.00 & 1.79 \\
\hline & 0.089 & 0.13 \\
\hline & $\begin{array}{c}\text { Caucasians } \\
\text { (excluding controls) }\end{array}$ & Afro-Caribbeans \\
\hline $\begin{array}{l}\text { Median total cell count } \\
\text { (number of cells } / \mathrm{mm}^{2} \text { ) } \\
n=11\end{array}$ & 1.43 & 1.79 \\
\hline $\begin{array}{l}\text { Median mast cell count } \\
\text { (number of cells } / \mathrm{mm}^{2} \text { ) } \\
n=8\end{array}$ & 0.092 & 0.13 \\
\hline
\end{tabular}

Most glaucoma patients take eye drops to lower their intraocular pressures to try and prevent disease progression. Some patients require glaucoma surgery, if medical treatment does not achieve an adequately reduced target intraocular pressure or if the patient develops allergic reactions to the topical medications. However, several investigators have suggested that the prolonged medical treatment may prejudice the success of surgical treatment priming the conjunctival cellular population for an excessive response to surgical wounding. Prolonged medical treatment has been reported to stimulate increased conjunctival cell expression of the inflammatory cell marker HLA-DR. ${ }^{14,15}$

Sherwood et $\mathrm{al}^{16}$ (using toluidine blue staining and cell morphology techniques) reported a significant increase in macrophages, lymphocytes, mast cells, and fibroblasts in the group of glaucoma patients who had received more than two types of drops for at least 1 year

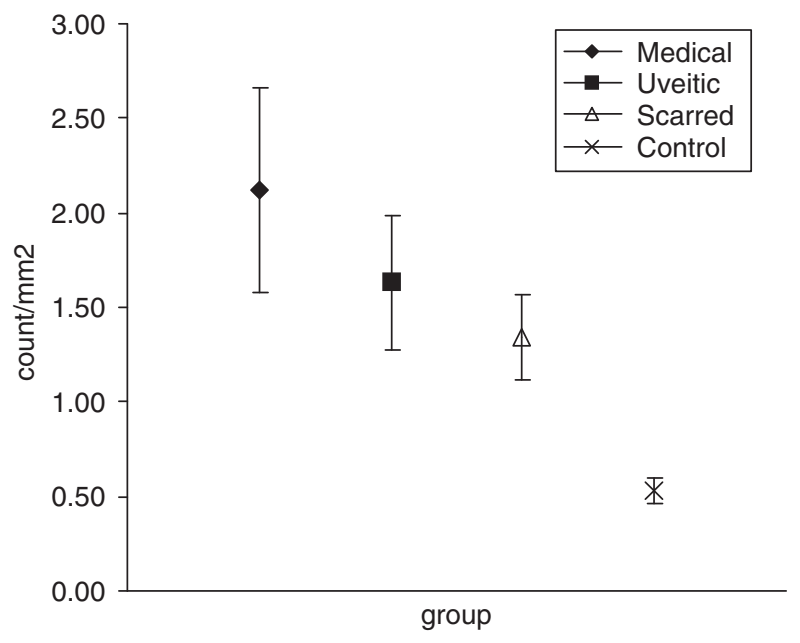

Figure 2 Graphical representation of the total cell count per $\mathrm{mm}^{2}$ for all the groups. The groups are medicated (M), uveitic (U), scarred (S), and control (C). Standard error bars are shown.

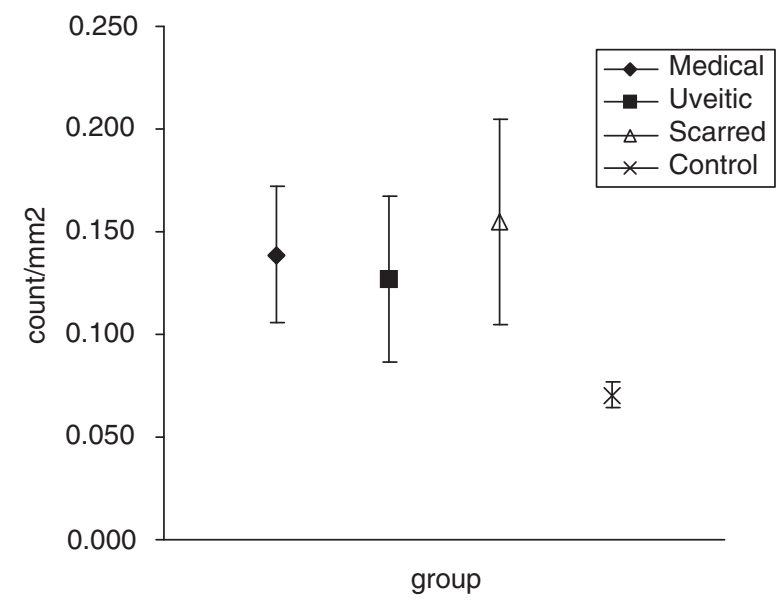

Figure 3 Graphical representation of the mast cell count per $\mathrm{mm}^{2}$ for all the groups. The groups are medicated (M), uveitic (U), scarred (S), and control (C). Standard error bars are shown.

compared with glaucoma patients who underwent filtration surgery as a primary treatment. Broadway et $a l^{17}$ reported that glaucoma patients who had received multiple topical treatments have a lower success rate after filtration surgery compared with those who undergo primary trabeculectomy. Our study agreed with earlier studies indicating an increase in total cell numbers associated with prolonged medical treatment in some glaucoma patients.

The failure of glaucoma surgery is associated with an excessive wound healing response. Hitchings and Grierson $^{1}$ reported a marked inflammatory response with early onset surgical failures (trabeculectomies less 
than 6 months). In their study, the inflammatory infiltrate (identified morphologically with toluidine blue) appeared to consist of macrophages and lymphocytes. The advantage of our study was that by using a tryptasestaining antibody, we were able to specifically identify that mast cells made up a part of the increased cell population in glaucoma patients.

All patients (except one) in all the glaucoma groups were on glaucoma medications. Our study's findings suggested that patients undergoing repeat glaucoma surgery have increased mast cell numbers preoperatively, and this abnormal conjunctival cellularity could predispose to an excessive postoperative wound healing response. This histological difference may also explain why some uveitic and medicated glaucoma patients do badly after surgery. Statistical significance was not reached for groups $U$ and $M$ - the reasons for this may be that the study consisted of small numbers for each group, varying glaucoma medication regimes and differing ethnicities.

The control group was the only group consisting of Caucasian patients only. All the glaucoma groups contained diverse ethnicities. Our study did not find any differences in conjunctival total and mast cell counts when Caucasian glaucoma patients were compared with Afro-Caribbean glaucoma patients. The numbers of AfroCaribbean patients were modest, and the study would have to be considerably larger to address this issue completely. Another possible explanation for the increase in mast cell numbers in the scarred group (group S) compared with the other glaucoma groups may be that the postoperative conjunctiva of glaucoma patients contained an altered cell population, and the reintroduction of medical treatment further changed the conjunctival population. Our study did not find any evidence of tissue remodelling as demonstrated by the lack of alpha smooth-muscle actin staining (staining not shown). This marker indicated the presence of differentiated myofibroblasts during the remodelling stage of wound healing. It may be that the predisposing process consisted of priming the conjunctiva with inflammatory cells rather than the cells that make scar tissue.

We can improve the success of glaucoma surgery by further understanding the preoperative conjunctival environment of our glaucoma patients. The preoperative modification of important conjunctival factors that increase the risk of postoperative scarring might play an important role in optimising our glaucoma patients' preoperative preparation for surgery. Our study showed that MCT staining was significantly increased in glaucoma patients who had undergone previous filtration surgery. If this relationship proves to be significant as far as wound healing is concerned, this increase could be potentially modifiable as antimast cell drugs are already available. The next stage of this project would be to further evaluate any other significant mast cell mediators in conjunctival scarring and to develop a practical, preoperative clinical test for evaluating the mast cell profile of glaucoma patients.

\section{Acknowledgements}

We thank the special Trustees of the Moorfields Eye Hospital NHS Trust, the Biomedical Research Centre, London, UK and Rosalind Hart and Heidi Barnes from the Institute of Ophthalmology, London, UK. This work has been presented as a poster at ARVO 2007.

\section{References}

1 Hitchings RA, Grierson I. Clinico pathological correlation in eyes with failed fistulizing surgery. Trans Ophthalmol Soc UK 1983; 103: 84-88.

2 Broadway DC, Grierson I, O'Brien C, Hitchings RA. Adverse effects of topical antiglaucoma medication. I. The conjunctival cell profile. Arch Ophthalmol 1994; 112: 1437-1445.

3 Leonardi A, Secchi AG. Vernal keratoconjunctivitis. Int Ophthalmol Clin 2003; 43: 41-58.

4 Church MK, McGill JI. Human ocular mast cells. Curr Opin Allergy Clin Immunol 2002; 2: 419-422.

5 McMillan TA, Stewart WC, Hennis HL, Hunt HH, Apple DJ. Histologic differences in the conjunctiva of black and white glaucoma patients. Ophthalmic Surg 1992; 23: 762-765.

6 Broadway D, Grierson I, Hitchings R. Racial differences in the results of glaucoma filtration surgery: are racial differences in the conjunctival cell profile important? $\mathrm{Br} J$ Ophthalmol 1994; 78: 466-475.

7 Trautmann A, Toksoy A, Engelhardt E, Brocker EB, Gillitzer R. Mast cell involvement in normal human skin wound healing: expression of monocyte chemoattractant protein-1 is correlated with recruitment of mast cells which synthesize interleukin-4 in vivo. J Pathol 2000; 190: 100-106.

8 Trautmann A, Krohne G, Brocker EB, Klein CE. Human mast cells augment fibroblast proliferation by heterotypic cell-cell adhesion and action of IL-4. J Immunol 1998; 160: 5053-5057.

9 Egozi EI, Ferreira AM, Burns AL, Gamelli RL, Dipietro LA. Mast cells modulate the inflammatory but not the proliferative response in healing wounds. Wound Repair Regen 2003; 11: 46-54.

10 Beer TW, Baldwin H, West L, Gallagher PJ, Wright DH. Mast cells in pathological and surgical scars. Br J Ophthalmol 1998; 82: 691-694.

11 Leonardi A, Radice M, Fregona IA, Plebani M, Abatangelo G, Secchi AG. Histamine effects on conjunctival fibroblasts from patients with vernal conjunctivitis. Exp Eye Res 1999; 68: 739-746.

12 Leonardi A, Brun P, Tavolato M, Abatangelo G, Plebani M, Secchi AG. Growth factors and collagen distribution in vernal keratoconjunctivitis. Invest Ophthalmol Vis Sci 2000; 41: 4175-4181. 
13 Powers MR, Qu Z, O'Brien B, Wilson DJ, Thompson JE, Rosenbaum JT. Immunolocalization of bFGF in pterygia: association with mast cells. Cornea 1997; 16: 545-549.

14 Nuzzi R, Vercelli A, Finazzo C, Cracco C. Conjunctiva and subconjunctival tissue in primary open-angle glaucoma after long-term topical treatment: an immunohistochemical and ultrastructural study. Graefes Arch Clin Exp Ophthalmol 1995; 233: 154-162.

15 Baudouin C, Hamard P, Liang H, Creuzot-Garcher C, Bensoussan L, Brignole F. Conjunctival epithelial cell expression of interleukins and inflammatory markers in glaucoma patients treated over the long term. Ophthalmology 2004; 111: 2186-2192.

16 Sherwood MB, Grierson I, Millar L, Hitchings RA. Longterm morphologic effects of antiglaucoma drugs on the conjunctiva and Tenon's capsule in glaucomatous patients. Ophthalmology 1989; 96: 327-335.

17 Broadway DC, Grierson I, O'Brien C, Hitchings RA.

Adverse effects of topical antiglaucoma medication. II. The outcome of filtration surgery. Arch Ophthalmol 1994; 112: 1446-1454. 